\title{
Gambaran pengetahuan ibu premenopause tentang hipertensi
}

\author{
Bernadetta Ambarita $^{1 \star}$, Desriati Sinaga ${ }^{1}$, Lidia Novarina Manalu ${ }^{1}$ \\ ${ }^{1}$ Sekolah Tinggi Ilmu Kesehatan Santa Elisabeth
}

\begin{abstract}
ABSTRAK
Hipertensi dapat menimbulkan berbagai keluhan yang sering dikaitkan dengan menopause. Pengetahuan yang cukup tentang hipertensi dapat membantu wanita dalam memelihara dan meningkatkan kesehatan, terutama dari risiko penyakit hipertensi. Penelitian ini merupakan penelitian deskriptif yang bertujuan mendapatkan gambaran pengetahuan ibu premenopause tentang hipertensi. Penelitian ini dilakukan pada bulan April 2021. Populasi pada penelitian ini adalah ibu premenopause di Klinik Bidan Kristina Kabupaten Dairi Sidikalang sebanyak 20 orang yang diambil keseluruhan menjadi sampel. Hasil penelitian menunjukkan bahwa mayoritas responden memiliki tingkat pengetahuan yang baik. Namun masih dijumpai tingkat pengetahuan yang rendah pada responden dengan jumlah yang mendekati responden dengan tingkat pengetahuan yang baik. Mayoritas informasi mengenai hipertensi berasal dari teman.
\end{abstract}

Kata kunci: pengetahuan, hipertensi, premenopause

Hypertension can cause various complaints that are often associated with menopause. Sufficient knowledge about hypertension can help women in maintaining and improving health, especially from the risk of hypertension. This study is a descriptive study that aims to obtain a description of the knowledge of premenopausal mothers about hypertension. This study was conducted in April 2021. The population in this study were premenopausal women at the Kristina Midwife Clinic, Dairi Sidikalang Regency, 20 people were taken as a whole as a sample. The results showed that the majority of respondents had a good level of knowledge. However, there is still a low level of knowledge in respondents with a number that is close to respondents with a good level of knowledge. The majority of information about hypertension comes from friends.

Keywords: knowledge, hypertension, premenopause

*Alamat korespondensi: bernadettaambarita@gmail.com DOI: $10.34012 / j p m s . v 4 i 1.2213$

\section{PENDAHULUAN}

Hipertensi didefinisikan sebagai keadaan tekanan darah sistolik $\geq 140 \mathrm{mmHg}$ dan atau tekanan darah diastolik $\geq 90 \mathrm{mmHg}$. Hipertensi adalah kelainan sistem sirkulasi darah yang mengakibatkan peningkatan tekanan darah di atas nilai normal atau tekanan darah $\geq 140 / 90 \mathrm{mmHg} .{ }^{1}$ Hipertensi merupakan masalah kesehatan publik utama di seluruh dunia dan merupakan faktor risiko penyakit kardiovaskular yang paling sering terjadi, serta belum terkendali secara optimal di seluruh dunia. ${ }^{2}$ Hipertensi berdasarkan kriteria Joint National Commite (JNC) VII, didefinisikan sebagai kondisi dimana tekanan darah sistolik lebih dari atau sama dengan $140 \mathrm{mmHg}$ dan tekanan darah diastolik lebih dari atau sama dengan $90 \mathrm{mmHg}$. $^{3}$ Hipertensi menyumbang 1 dari 5 kematian di antara wanita Amerika, menimbulkan beban yang lebih besar bagi wanita daripada pria, dan merupakan salah satu faktor risiko terpenting mereka untuk kematian, perkembangan penyakit kardiovaskular dan penyakit lainnya. ${ }^{4}$

Wanita lanjut usia juga memiliki hipertensi yang lebih parah dan tingkat kontrol tekanan darah yang lebih rendah dibandingkan wanita paruh baya dan muda. ${ }^{5}$ Hipertensi pada wanita ibu premenopause dapat dipengaruhi stress. Hasil penelitian Ardiani (2015) tentang faktor risiko hipertensi 
pada wanita menopause menunjukkan bahwa ada hubungan antara tingkat stres yang tinggi dengan kejadian hipertensi pada wanita menopause $(\mathrm{p}=0,001) .{ }^{6}$ Premenopause dapat diartikan sebagai haid alami terakhir. premeopause dapat diartikan sebagai tidak dijumpainya menstruasi selama 12 bulan berturutturut. Ovarium secara progresif telah gagal dalam memproduksi estrogen. Menopause juga dapat diartikan dengan peningkatan jumlah folikel yang mengalami atresia, sampai suatu ketika tidak tersedia lagi folikel yang cukup. Sehingga produksi estrogen berkurang dan tidak terjadi haid lagi yang berakhir dengan terjadinya menopause. ${ }^{7}$

Pada transisi menopause banyak wanita mengalami gejala vasomotor yang dapat mempengaruhi aktivitas normal mereka sehari-hari. Dengan penurunan kadar estrogen, faktor risiko penyakit jantung koroner menjadi lebih jelas, terutama hipertensi. Timbulnya hipertensi dapat menimbulkan berbagai keluhan yang sering dikaitkan dengan menopause. Identifikasi faktor risiko tidak dikelola dengan baik pada wanita paruh baya dan harus menjadi langkah pertama dalam evaluasi dan pengobatan wanita dengan gejala perimenopause. Pada wanita dengan risiko rendah untuk penyakit jantung koroner, masih ada peluang untuk resep hormon yang aman di tahun-tahun pertama setelah menopause. ${ }^{8}$

Wanita yang mengalami hipertensi dipengaruhi kurangnya pengetahuan ibu premenopuse tentang hipertensi. Pengetahuan yang cukup tentang hipertensi dapat membantu wanita menopause dalam memelihara dan meningkatkan kesehatan, terutama dari penyakit hipertensi. Studi ini bertujuan untuk melihat gambaran pengetahuan ibu premenopause tentang hipertensi.

\section{METODE}

Penelitian ini merupakan penelitian deskriptif yang bertujuan mendapatkan gambaran pengetahuan ibu premenopause tentang hipertensi. Penelitian ini dilakukan pada bulan April 2021. Populasi pada penelitian ini adalah ibu premenopause di Klinik Bidan Kristina Kabupaten Dairi Sidikalang sebanyak 20 orang yang diambil keseluruhan menjadi sampel.

Variabel dalam penelitian ini yaitu gambaran pengetahuan ibu premenopause tentang hipertensi. Alat ukur yang digunakan untuk pengumpulan data pada penelitian ini adalah kuesioner. Kuesioner yang digunakan bersifat pertanyaan terbuka di mana dalam kuesioner tersebut jika responden bisa menjawab kuesioner dengan benar maka dapat nilai $=1$ jika salah dapat nilai $=0$. jumlah kuesioner yang disediakan berjumlah 20 pertanyaan. Arikunto (2010) membuat kategori tingkat pengetahuan seseorang menjadi 2 yaitu tingkat pengetahuan kategori baik jika nilainya $<76-100 \%$ dan tingkat pengetahuan kategori cukup jika nilainya $56-5 \%$.

\begin{tabular}{lcc}
\multicolumn{3}{c}{ Tabel 1. Karakteristik responden $(\mathrm{n}=20)$} \\
Variabel & Jumlah & Persentase \\
Penelitian & 4 & 20,0 \\
$\quad$ Tidak sekolah & 2 & 10,0 \\
SD & 4 & 20,0 \\
SMP & 7 & 35,0 \\
SMA & 3 & 15,0 \\
Sarjana & & \\
Pekerjaan & 2 & 10,0 \\
Ibu rumah tangga & 9 & 45,0 \\
Petani & 5 & 25,0 \\
Swasta & 4 & 20,0 \\
PNS & & \\
Sumber informasi & 3 & 15,0 \\
Internet & 9 & 45,0 \\
Teman & 6 & 30,0 \\
Orangtua & 2 & 10,0 \\
Tenaga kesehatan & &
\end{tabular}

\section{HASIL}

Tabel 1 menunjukkan bahwa berdasarkan pendidikan jumlah keseluruhan tidak sekolah sebanyak 4 orang $(20,0 \%)$, tamat SD sebanyak 2 orang (10,0\%), tamat SMP sebanyak 4 orang $(20,0 \%)$, tamat SMA sebanyak 7 orang $(35,0 \%)$, dan sarjana sebanyak 3 orang $(15,0 \%)$. Berdasarkan pekerjaan, jumlah IRT sebanyak 2 orang $(10,0 \%)$, petani 9 orang $(45,0 \%)$, swasta 5 orang $(25,0 \%)$, dan PNS 4 orang $(20,0 \%)$. Berdasarkan sumber informasi, responden memperoleh informasi dari internet sebanyak 3 
orang $(15,0 \%)$, dari teman sebanyak 9 orang $(45,0 \%)$, bersumber orang tua sebanyak 6 orang $(30,0 \%)$, dan dari tenaga kesehatan sebanyak 2 orang $(10,0 \%)$.

Tabel 2. Distribusi frekuensi pengetahuan $(n=20)$

$\begin{array}{lcc}\text { Variabel } & \text { Jumlah } & \text { Persentase } \\ \text { Pengetahuan } & & \\ \text { Baik } & 9 & 45,0 \\ \text { Cukup } & 3 & 15,0 \\ \text { Kurang } & 8 & 40,0\end{array}$

Pada tabel 2 dapat dilihat bahwa responden paling banyak memiliki tingkat pengetahuan yang baik (45,0\%). Responden dengan tingkat pengetahuan kurang sebanyak 8 orang $(40,0 \%)$.

\section{PEMBAHASAN}

Pendidikan dan pengetahuan dapat mempengaruhi seseorang untuk memanfaatkan fasilitas kesehatan yang ada, termasuk melakukan kunjungan pemeriksaan berkaitan dengan kejadian hipertensi yang dialami oleh responden. Semakin tinggi pendidikan maka akan mudah menerima hal-hal baru dan mudah menyesuaikan dengan hal yang baru. Sebaliknya, semakin rendah tingkat pendidikan akan menghambat perkembangan sikap seseorang terhadap nilai-nilai yang baru diperkenalkan. ${ }^{9}$ Selain pendidikan, usia juga mempengaruhi pola pikir seseorang dalam menerima informasi. Pengalaman merupakan sumber pengetahuan, oleh sebab itu pengalaman pribadi dapat dijadikan upaya untuk memperoleh pengetahuan. ${ }^{4}$ Pendidikan yang dijalani seseorang sangat memiliki pengaruh yang berpendidikan lebih tinggi akan dapat mengambil keputusan lebih rasional umumnya terbuka untuk menerima perubahan hal baru dibandingkan dengan Pendidikan rendah.

Dari hasil penelitian dapat diketahui bahwa pekerjaan mempengaruhi pengetahuan ibu premenopause. Hal ini dapat dilihat bahwa ibu premenopause dengan pekerjaan sebagai petani lebih banyak memiliki pengetahuan cukup dan dengan pekerjaan ibu rumah tangga lebih sedikit memiliki pengetahuan kurang. Pekerjaan akan berpengaruh besar terhadap sosial ekonomi, dan pola pikir seseorang. Rata-rata ibu bekerja sehingga ibu premenopause mempunyai wawasan dan pergaulan yang cukup luas. Selain itu, pihak klinik juga selalu memberikan edukasi setiap tahunnya sehingga pengetahuan ibu atau responden menjadi lebih baik tentang pentingnya pemberian edukasi mengenai hipertensi pada ibu premenopause.

Tingkat pengetahuan juga berkaitan dengan sumber informasi yang diperoleh seseorang. Sumber informasi bisa didapatkan berupa data, teks, gambar, suara, kode, program komputer, dan basis data yang dapat memberikan pengaruh jangka pendek (immediate impact). Oleh karena itu, sumber informasi dapat mempengaruhi pengetahuan seseorang berupa perubahan atau peningkatan pengetahuan..$^{10}$

\section{KESIMPULAN}

Studi ini menyimpulkan bahwa mayoritas responden memiliki tingkat pengetahuan yang baik. Namun masih dijumpai tingkat pengetahuan yang rendah pada responden dengan jumlah yang mendekati responden dengan tingkat pengetahuan yang baik. Mayoritas informasi mengenai hipertensi berasal dari teman.

\section{REFERENSI}

1. Brunner S, Smetzer SC, Bare BG. Buku Ajar Keperawatan Medikal- Bedah Brunner Suddarth. Jakarta: EGC; 2013.

2. Kjeldsen SE. Hypertension and cardiovascular risk: General aspects. Pharmacol Res [Internet]. 2018;129:95-9. Available from: https://www.sciencedirect.com/science/article/pii/S1043661817311180

3. Chobanian A V, Bakris GL, Black HR, Cushman WC, Green LA, Izzo JLJ, et al. The Seventh Report of the Joint National Committee on Prevention, Detection, Evaluation, and Treatment of High Blood Pressure: the JNC 7 report. JAMA. 2003 May;289(19):2560-72. 
4. Wenger NK, Arnold A, Bairey Merz CN, Cooper-DeHoff RM, Ferdinand KC, Fleg JL, et al. Hypertension Across a Woman's Life Cycle. J Am Coll Cardiol [Internet]. 2018 Apr 24;71(16):1797-813. Available from: https://pubmed.ncbi.nlm.nih.gov/29673470

5. Benjamin EJ, Blaha MJ, Chiuve SE, Cushman M, Das SR, Deo R, et al. Heart Disease and Stroke Statistics2017 Update: A Report From the American Heart Association. Circulation. 2017 Mar;135(10):e146-603.

6. Ardiani H, Saraswati LD, Susanto HS. Risk Factors of Hypertension in Menopausal Women in Rejomulyo, Madiun. Makara J Heal Res. 2015;19(2):61-6.

7. Proverawati A. Menopause dan Sindrome Premenopause. Yogyakarta: Nuha Medika; 2010.

8. Maas AHEM, Franke HR. Women's health in menopause with a focus on hypertension. Neth Heart J [Internet]. 2009 Feb;17(2):68-72. Available from: https://pubmed.ncbi.nlm.nih.gov/19247469

9. Mubarak W., Rozikin N, Supradi K. Promosi Kesehatan: Sebuah Pengantar Proses Belajar Mengajar dalam Pendidikan. Yogyakarta: Graha Ilmu; 2007.

10. Budiman, Riyanto A. Kapita Selekta Kuesioner: Pengetahuan dan Sikap dalam Penelitian Kesehatan. Jakarta: Salemba Medika; 2013. 